\title{
Penggunaan Discovery Learning Berbantuan Laboratorium Virtual pada Penguasaan Konsep Fisika Siswa
}

\author{
${ }^{1}$ Putri Iman Sari, ${ }^{2}$ Gunawan, ${ }^{2}$ Ahmad Harjono \\ ${ }^{1,2}$ Program Studi Pendidikan Fisika \\ Universitas Mataram \\ Mataram, Indonesia \\ Email : putriimans@gmail.com
}

\begin{abstract}
Discovery learning is a way of teaching that gives students the knowledge to construct a concept discovered through an experiment. The implementation of the experiment will be more effectively done by utilizing the media realized in computer technology, one of which uses virtual laboratory. This study aims to improve students' mastery of concepts of physics discovery aided by the application of learning virtual lab. The results showed that the increase in student mastery of concepts taught Using discovery learning assisted higher laboratoium more than the students who are not being treated. Mastery of concepts in each sub-material has increased significantly, except in the concept of electrical measuring instrument control group is superior to 1\% compared to the experimental group.
\end{abstract}

Keywords: discovery learning, virtual laboratory, mastery of concepts.

\section{PENDAHULUAN}

Fisika merupakan salah satu bagian dari sains yang mempelajari berbagai benda-benda di alam, gejala-gejala maupun fenomena-fenomena yang terjadi di alam. Pada hakikatnya fisika mencakup aspek produk, proses, dan sikap. Dalam aspek poduk, fisika dipandang sebagai sekumpulan pengetahuan yang berupa fakta, konsep, generalisasi, prinsip, teori, dan hukum fisika. Sementara pada aspek proses, fisika merupakan serangkaian proses ilmiah yang dilakukan dalam menemukan pengetahuanpengetahuan tentang fisika. Pengetahuan fisika yang diperoleh melalui serangkaian proses ilmiah seperti melakukan pengukuran, percobaan, dan diskusi serta melibatkan siswa secara langsung dalam kegiatan tersebut akan membantu mereka memahami konsep-konsep yang ada. Pada kenyataannya, pembelajaran fisika di sekolah lebih dominan memperlakukan fisika sebagai sekumpulan pengetahuan. Hal ini ada kaitannya dengan proses pembelajaran yang masih berpusat pada guru. Siswa hanya mendapatkan konsepkonsep yang bersifat informasi yang disampaikan guru di kelas. Pembelajaran yang sepenuhnya menyampaikan materi tanpa melibatkan siswa langsung dalam pembelajaran, menyebabkan siswa kurang tertarik untuk belajar sehingga berdampak pada berkurangnya motivasi dan keaktifan mereka selama proses pembelajaran.
Hal ini kemudian berimplikasi pada rendahnya penguasaan konsep fisika siswa.

Upaya mengatasi permasalahan tersebut diperlukan suatu inovasi model pembelajaran berpusat pada siswa dengan melibatkan peran aktif siswa dan dapat memberi kesempatan membangun pengetahuan di dalam benak mereka. Salah satunya dengan menerapkan model pembelajaran berbasis kontruktivisme yaitu model discovery learning.

Pembelajaran discovery merupakan pembelajaran berbasis penemuan. Pembelajaran discovery merupakan rangkaian kegiatan pembelajaran dimana guru menyajikan bahan ajar tidak dalam bentuk final, melainkan memberi peluang untuk mencari dan menemukan sendiri konsep terhadap materi yang dipelajari [1]. Melalui pembelajaran ini, siswa dapat belajar dengan lebih mandiri dan mengkontruksi pengetahuan yang diperoleh dari hasil pemikiran serta terlatih dalam menyelesaikan masalah yang dihadapi. Hasil penelitian Widiadnyana et al [2] dan Putrayasa et al [3] membuktikan bahwa penerapan model discovery learning dapat meningkatkan pemahaman konsep dan hasil belajar IPA siswa.

Disisi lain rendahnya penguasaan konsep juga disebabkan karena adanya kesulitan siswa dalam memahami konsep-konsep fisika yang tergolong abstrak. Konsep abstrak merupakan 
konsep yang sulit untuk divisualisasikan dalam laboratorium nyata sekalipun. Namun seiring dengan perkembangan IPTEK yang sangat pesat, kini konsep-konsep yang bersifat makroskopik, mikroskopik, maupun abstrak sekalipun telah dapat divisualisasikan dalam suatu media berbasis komputer, salah satunya adalah media laboratorium virtual.

Laboratorium virtual merupakan seperangkat software yang menyediakan sarana dan prasarana untuk melakukan kegiatan eksperimen yang terdiri atas simulasi, animasi, video serta menyediakan alat-lat eksperimen [4]. Melalui media ini kita dapat melakukan kegiatan eksperimen tanpa memerlukan adanya alat-alat laboratorium riil. Penelitian terdahulu membuktikan bahwa penggunaan laboratorium virtual pengembangan konsep fisika lebih baik dibandingkan laboratorium riil [5].

Media ini juga dapat menjadi salah satu alternatif dalam mengatasi kegiatan praktikum yang jarang dilakukan dibeberapa sekolah. Hal ini disebabkan karena keterbatasan alat-alat praktikum yang kurang memadai ataupun fungsi ruang laboratorium yang dijadikan sebagai ruang kelas untuk belajar sehingga kegiatan praktikum menjadi kurang efektif. Selain itu, dengan menggabungkan model discovery learning dengan bantuan media laboratorium virtual memungkinkan proses pembelajaran menjadi lebih efektif. Pembelajaran discovery berbantuan laboratorium virtual memberi kesempatan kepada siswa memperoleh pengalaman dan melakukan percobaan dalam menemukan sendiri konsep-konsep fisika. Dengan demikian, peneliti bermaksud melakukan penelitian dengan menggunakan model pembelajaran discovery berbantuan laboratorium virtual dengan harapan dapat meningkatkan pengusaan konsep fisika siswa.

\section{TINJAUAN PUSTAKA}

Discovery dalam bahasa indonesia berarti penemuan. Discovery learning memberi kesempatan kepada siswa belajar mencari dan menemukan sendiri. Menurut Asril [6] dalam sistem pembelajaran ini guru menyajikan bahan ajar tidak dalam bentuk yang final, tetapi siswa diberi peluang untuk mencari dan menemukannya sendiri dengan mempergunakan teknik pendekatan pemecahan masalah Kosasih [1] mengungkapkan bahwa pembelajaran ini mengarahkan siswa untuk dapat menemukan sesuatu melalui proses pembelajaran yang dilakoninya layak seorang saintis. Mereka diharapkan bisa berperan aktif bahkan sebagai pelaku dari pencipta ilmu pengetahuan. Roestiyah [7] mendefinisikan discovery learning sebagai suatu cara mengajar yang melibatkan siswa dalam proses kegiatan mental melalui tukar pendapat, dengan diskusi, seminar, membaca sendiri dan mencoba sendiri, agar anak dapat belajar sendiri.

Adapun langkah-langkah dalam discovery learning dibagi menjadi enam tahapan yakni stimulasi/pemberian rangsangan, identifikasi masalah, pengumpulan data, pengolahan data, verifikasi, dan generalisasi/kesimpulan [8]. Ada beberapa kelebihan dan kelemahan dari model discovery learning. Kelebihannya antara lain menambah pengalaman siswa dalam belajar, memberikan kesempatan untuk lebih dekat dengan sumber pengetahuan, menggali kreatifitas, mampu meningkatkan percaya diri, dan meningkatkan kerja sama antar siswa [3]. Selain itu, siswa dapat belajar memecahkan masalah secara mandiri dan keterampilan berpikir kritis karena harus selalu menganalisis dan menangani informasi [9]. Sedangkan kelemahan dalam discovery learning yakni dalam pelaksanaannya memakan waktu yang cukup banyak dan jika kurang terpimpin atau terarah dapat menjurus kepada kekacauan dan kekaburan atas materi yang dipelajari [6].

Salah satu media yang dapat digunakan dalam memvisualisasikan materi fisika khususnya pada konsep-konsep abstrak adalah laboratorium virtual. Laboratorium virtual disajikan dalam bentuk perangkat lunak (software) berbasis komputer. Laboratorium virtual didefinisikan sebagai suatu bentuk objek multimedia interaktif [10]. Objek multimedia interakif ini terdiri dari berbagai macam format heterogen diantaranya teks, hiperteks, suara, gambar, animasi, video, grafik, dan simulasi. Selain itu, laboratorium virtual mampu mensimulasi percobaan laboratorium ke dalam komputer yang juga disajikan dalam bentuk objek multimedia interaktif [4]. Laboratorium virtual merupakan serangkaian program yang dapat memvisualisasikan fenomena yang abstrak atau percobaan sehingga dapat meningkatkan aktivitas belajar dalam upaya mengembangkan keterampilan yang dibutuhkan dalam pemecahan masalah [11]. Sebuah laboratorium virtual memberikan banyak keuntungan yaitu dapat melakukan percobaan berbahaya tanpa 
membahayakan dirimu atau orang lain, simulasi yang terjangkau, dapat dilakukan kapan saja, tidak membutuhkan banyak biaya, hasil percobaan yang diperoleh selalu sama, serta laboratorium virtual memungkinkan untuk bekerja independen atau kolaboratif berkaitan dengan pelajaran [12]. Gunawan et al [13] juga mengungkapkan bahwa penggunaan multimedia interaktif efektif dalam mendukung proses pembelajaran fisika.

Media laboratorium virtual yang peneliti gunakan dalam penyampaian materi mengenai listrik dinamis adalah simulasi Phet CCK (Construction Circuit Kit). Simulasi ini menyediakan alat-alat percobaan listrik yang dirancang sedemikian rupa untuk melakukan kegiatan eksperimen sehingga membantu siswa lebih mudah menemukan konsep-konsep listrik dinamis.

Konsep merupakan kondisi utama yang diperlukan untuk menguasai kemahiran diskriminasi dan proses kognitif fundamental sebelumnya berdasarkan kesamaan ciri-ciri sekumpulan stimulus dan objek-objeknya. Kemampuan seseorang dalam menguasai ciriciri atau menggolongkan objek-objek maupun kejadian-kejadian disekitar maka dibutuhkan kemampuan penguasaan konsep. Dahar [14] mengartikan penguasaan konsep sebagai kemampuan siswa dalam memahami makna secara ilmiah baik teori maupun penerapannya dalam kehidupan sehari-hari. Silaban [15] mendefinisikan penguasaan konsep sebagai usaha yang harus dilakukan siswa dalam merekam dan mentransfer kembali sejumlah informasi dari suatu materi pelajaran tertentu yang dapat dipergunakan dalam memecahkan masalah, menganalisis, meginterpetasikan pada suatu kejadian tertentu. Melalui kemampuan penguasaan konsep fisika yang baik akan membantu siswa dalam pemecahan masalah yang dihadapi.

Penguasaan konsep merupakan salah satu bagian dari kompetensi kognitif. Pengukuran penguasaan konsep dalam penelitian ini adalah kemampuan kognitif siswa yang merujuk pada indikator taksonomi Bloom yang disempurnakan oleh Anderson \& Krathwohl [16] yaitu $\mathrm{C} 1$ (mengingat), C2 (memahami), C3 (mengaplikasi), C4 (menganalisis), C5 (evaluasi), dan C6 (mencipta).

\section{METODE PENELITIAN}

Penelitian kuasi eksperimen ini ditandai dengan adanya perlakuan yang dirancang dan diberikan secara sengaja untuk mengubah kondisi, namun peneliti tidak memiliki keleluasaan memanipulasi subjek [17]. Desain penelitian menggunakan pre-test post-test control group design, dalam pelaksanaannya diawali dengan pemberian tes awal kepada kedua kelompok sampel, kemudian kedua kelompok mendapatkan perlakuan yang berbeda yaitu kelompok eksperimen diberikan perlakuan berupa penerapan discovery learning berbantuan media laboratorium virtual sedangkan bagi kelompok kontrol diberikan perlakuan dengan menerapkan pembelajaran konvensional di sekolah berupa pengajaran langsung, dan diakhiri dengan dilakukan tes akhir pada kedua sampel.

Penelitian ini dilakukan pada siswa kelas X SMAN 3 Mataram tahun ajaran 2015/2016 dengan sampel yaitu 37 siswa sebagai kelompok eksperimen dan 35 siswa sebagai kelompok kontrol yang terpilih secara acak menggunakan teknik cluster random sampling.

Instrumen dalam pengumpulan data penelitian ini berupa tes penguasaan konsep berbentuk pilihan ganda berjumlah 35 soal. Sebelum digunakan untuk penelitian tes ini diuji cobakan kepada sekelompok siswa yang telah mempelajari materi listrik dinamis kemudian dilakukan uji validitas, reabilitas, taraf kesukaran, dan daya beda. Hasil analisis uji coba diperoleh 25 soal yang digunakan untuk tes awal dan akhir. Analisis data hasil penguasaan konsep pada tes awal dan akhir diawali dengan menguji prasyarat analisis yaitu uji homogenitas menggunakan uji varians atau uji-F dan uji normalitas menggunakan rumus uji chi kuadrat [18]. Dilanjutkan dengan menganalisis data hasil tes akhir menggunakan uji $\mathrm{t}$ polled varian. Sedangkan untuk mengetahui peningkatan penguasaan konsep pada setiap sub materi serta sebagai antisipasi kesalahan skor setiap siswa dianalisis menggunakan gain ternomalisasi $(n-$ gain).

\section{HASIL DAN PEMBAHASAN}

Hasil penelitian berupa deskripsi data hasil tes awal (sebelum perlakuan) dan tes akhir (setelah perlakuan) yang sudah di uji homogenitas, uji normalitas dan uji hipotesis. Perbandingan penguasaan konsep fisika pada kelas eksperimen dan kelas kontrol dapat diketahui berdasarkan perolehan nilai rata-rata tes awal dan akhir yang disajikan dalam Tabel 1 berikut. 
Tabel 1. Data Hasil Tes Awal Dan Tes Akhir Penguasaan Konsep Fisika

\begin{tabular}{llccccc}
\hline Kelas & Kemampuan & $\begin{array}{c}\text { Jumlah } \\
\text { Siswa }\end{array}$ & $\begin{array}{c}\text { Nilai } \\
\text { Terendah }\end{array}$ & $\begin{array}{c}\text { Nilai } \\
\text { Tertinggi }\end{array}$ & Rata-Rata & Varians \\
\hline \multirow{2}{*}{ Eksperimen } & Awal & 37 & 20.00 & 60.00 & 40.11 & 127.54 \\
& Akhir & 37 & 52.00 & 92.00 & 75.03 & 94.58 \\
\multirow{2}{*}{ Kontrol } & Awal & 35 & 12.00 & 64.00 & 34.40 & 173.36 \\
& Akhir & 35 & 44.00 & 84.00 & 62.40 & 158.30 \\
\hline
\end{tabular}

Tabel 1 menunjukkan bahwa sebelum diberi perlakuan kedua kelas memiliki kemampuan awal yang tidak berbeda jauh atau sama. Hal ini ditunjukkan dengan hasil analisis uji homogenitas pada data awal diperoleh $\mathrm{F}_{\text {hitung }}<$ $\mathrm{F}_{\text {tabel }}$ yaitu $1.36<1.76$ yang artinya kedua kelas homogen. Selain itu, kemampuan awal siswa tergolong rendah, hal ini disebabkan karena belum memperoleh materi listrik dinamis sesuai jenjangnya serta pengetahuan dasar yang dimiliki diperoleh di sekolah menengah pertama. Sedangkan berdasarkan hasil analisis uji normalitas diperoleh $\chi^{2}{ }_{\text {hitung }}<\chi^{2}{ }_{\text {tabel }}$ untuk kemampuan awal kelas eksperimen 4,80<11,07 dan kelas kontrol 3,56 < 11,07 yang berarti data terdistribusi normal.

Berdasarkan hasil tes akhir pada Tabel 1 menginformasikan bahwa adanya peningkatan penguasaan konsep pada kedua kelas. Kelas eksperimen memperoleh skor rata-rata yang lebih tinggi dibanding kelas kontrol dari nilai rata-rata tes awal. Selanjtunya data hasil tes akhir diuji homogenitas dan normalitas untuk menentukan jenis uji-t yang digunakan. Dari hasil analisis data diperoleh kedua kelas memiliki varians yang homogen dan data terdistribusi normal sehingga menggunakan uji t-test polled varians sebagai uji hipotesisnya. Diperoleh hasil bahwa $t_{\text {hitung }}>t_{\text {tabel }}$ dengan nilai $t_{\text {hitung }}$ sebesar 4.78 dan $t_{\text {tabel }}$ sebesar 1.99 pada taraf signifikan 5\%. Artinya terdapat perbedaan penguasaan konsep fisika siswa yang diajarkan menggunakan model discovery learning berbantuan media laboratorium virtual dengan pembelajaran secara konvensional. Maka dapat disimpulkan model discovery learning berbantuan laboratorium virtual berpengaruh terhadap penguasaan konsep fisika siswa.

Hal ini sesuai dengan hasil penelitian terdahulu dimana penggunaan model discovery learning dapat meningkatkan kemampuan pemahaman konsep IPA siswa [2], Hasil penelitian Hermansyah et al [19] juga membuktikan bahwa media laboratorium virtual berpengaruh terhadap penguasaan konsep dan kemampuan berpikir kreatif siswa. Temuan Sari et al [20] juga menunjukkan bahwa penggunaan simulasi komputer dalam discovery learning dapat meningkatkan hasil belajar siswa pada aspek kognitif (pengetahuan), psikomorik, dan sikap.

Berdasarkan hasil pengamatan peneliti selama proses pembelajaran berlangsung, terlihat bahwa perlakuan yang diberikan pada kelas ekperimen membuat siswa lebih aktif dan termotivasi untuk belajar sehingga meningkatkan pemahaman konsep fisika siswa. Pada tahap ke 3 pengumpulan data, siswa dilatih menemukan konsep-konsep fisika secara berkelompok melalui kegiatan eksperimen menggunakan media laboratorium virtual berupa simulasi Phet $C C K$. Penggunaan media ini sangat mendukung pembelajaran discovery dalam menemukan konsep-konsep listrik dinamis. Melalui $C C K$, siswa secara langsung melihat tentang apa yang sedang dipelajari, misalnya pada materi listrik dinamis, bisa dilihat bagaimana perbedaan nyalanya lampu saat dirangkai secar seri dan paralel, bahkan arah aliran muatan elektron dapat terlihat. Media laboratorium virtual ini membuat siswa termotivasi untuk menemukan konsepkonsep fisika dan siswa lebih bersemangat untuk belajar. Kemudian, pada akhir pembelajaran siswa diberikan latihan-latihan soal penguasaan konsep. Latihan tersebut diberikan agar siswa terbiasa mengaplikasikan konsep-konsep yang telah ditemukan sendiri sebelumnya dalam kehidupan nyata dan apa yang telah dipelajari akan tertanam lebih lama di otak siswa. Sehingga siswa memiliki kemampuan dalam mengungkapkan kembali konsep yang telah diperoleh sebelumnya yang kemudian berpengaruh positif terhadap peningkatan penguasaan konsep siswa.

Materi listrik dinamis dalam penelitian ini dibatasi pada 5 sub materi, yaitu arus listrik, hukum Ohm, rangkaian listrik, hukum Kirchoff, dan alat ukur listrik. Perbandingan persentase peningkatan penguasaan konsep siswa setiap sub materi kelas eksperimen dan kelas kontrol ditampilkan pada gambar 1 berikut. 


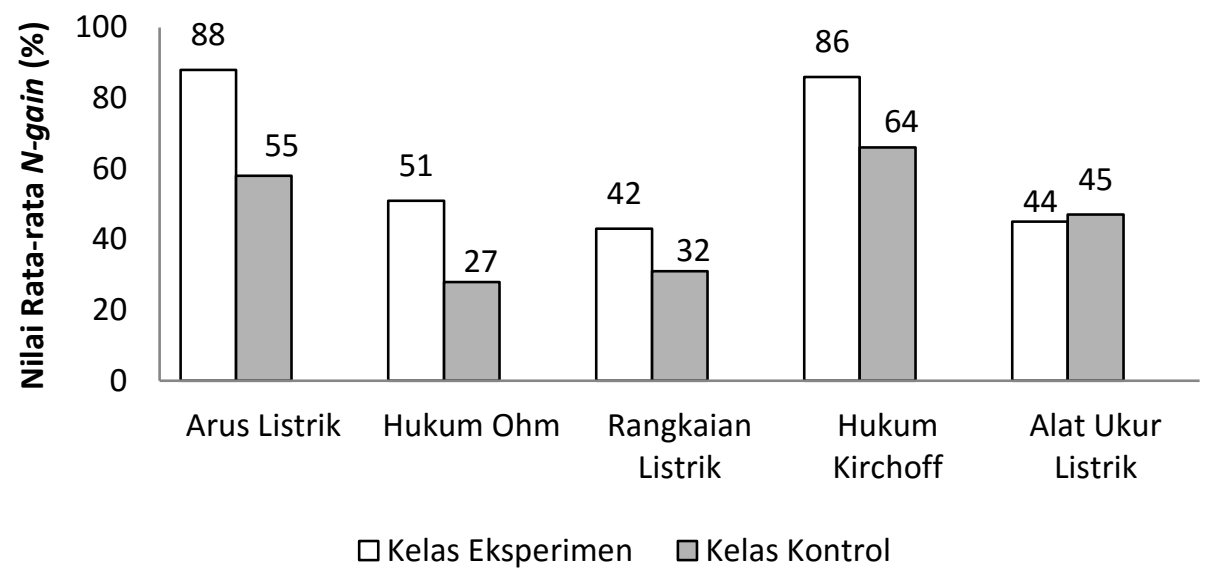

Gambar 1. Perbandingan Skor N-gain Penguasaan Konsep pada Kedua Kelas

Pada Gambar 1 terlihat bahwa terdapat perbedaan peningkatan penguasaan konsep antara kelas eksperimen dan kelas kontrol untuk setiap sub materi listrik dinamis. Secara keseluruhan peningkatan sub materi kelas eksperimen lebih tinggi dibandingkan kelas kontrol, kecuali pada materi alat ukur listrik.

Peningkatan tertinggi kelas eksperimen terdapat pada materi arus listrik sebesar $88 \%$ dan hukum Kirchoff sebesar $86 \%$, keduanya berada pada kategori tinggi. Peningkatan konsep arus listrik sangat dikuasai oleh siswa karena sebelumnya telah dipelajari di sekolah menengah pertama pada kelas IX semester 1 dan kemudian lebih ditekankan lagi menggunakan discovery learning berbantuan media laboratorium virtual sehingga membuat siswa dapat memahami konsep-konsep arus listrik dengan sangat baik.

Sedangkan peningkatan pada konsep hukum Kirchoff pada siswa eksperimen disebabkan karena selama proses pembelajaran fokus perhatian mereka untuk belajar lebih meningkat lagi. Kecakapan siswa dalam pengoperasian media laboratorium virtual yang digunakan pada kegiatan eksperimen untuk pengumpulan data sangat baik sehingga tidak membutuhkan banyak waktu dalam menyelesaikan permasalahan yang diberikan. serta secara keseluruhan siswa mampu menjawab pertanyaan pada LKS dengan benar. Sedangkan peningkatan terendah pada kelas eksperimen ditemukan dalam materi rangkaian listrik sebesar $42 \%$ berada pada kategori sedang. Rendahnya peningkatan konsep ini karena pada pertemuan kedua keterlaksanaan discovery learning di tahap 4 menganalisis data kurang maksimal. Kesulitan analisis pada percobaan kedua meningkat sehingga dibutuhkan waktu lebih lama bagi siswa untuk menganalisis data yang terkumpul dan menjawab pertanyaan yang ada pada LKS. Faktor lainnya disebabkan oleh faktor eksternal yang peneliti tidak dapat kontrol yaitu banyak siswa yang izin dengan alasan ada kegiatan ekstrakurikuler. Selanjutnya peningkatan kelas kontrol pada sub materi alat ukur listrik lebih tinggi $1 \%$ dari kelas eksperimen, namun hasil ini tidak terlalu berbeda signifikan. Artinya penguasaan konsep pada sub materi tersebut cukup merata antar kedua kelas.

Hasil analisis peningkatan penguasaan konsep fisika siswa yang ditinjau pada aspek kognitif C1 hingga C6 juga mengalami peningkatan yang cukup signifikan. 


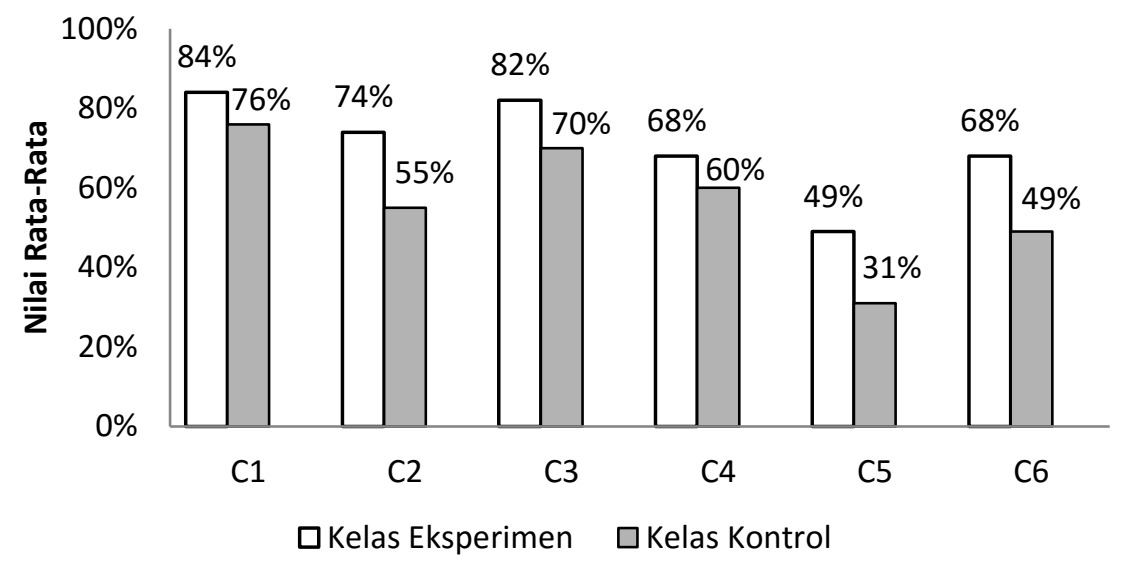

Gambar 2. Perbandingan Tes Akhir pada Setiap Ranah Kognitif Kedua Kelas

Gambar 2 menjelaskan bahwa secara keseluruhan kelas eksperimen mengalami peningkatan penguasaan konsep untuk setiap aspek kognitif lebih tinggi dibandingkan dengan kelas kontrol. Peningkatan tertinggi terdapat pada aspek kognitif $\mathrm{C} 1$ (mengingat). Instrumen penilaian untuk aspek kognitif rendah ini tergolong dalam kategori soal mudah dan sedang, sehingga siswa dapat menjawab dengan baik. Sedangkan peningkatan terendah terdapat pada aspek kognitif C5 yaitu mengevaluasi. Hal ini disebabkan karena keterbatasan waktu yang tersedia sehingga pada kegiatan akhir pembelajaran dimana guru memberikan evaluasi yaitu latihan soal penguasaan konsep. Akan tetapi guru tidak dapat membimbing penuh dalam latihan soal.

Berdasarkan uraian di atas, penerapan discovery learning berbantuan laboratorium virtual ini memberikan dampak positif antara lain, siswa memiliki keterampilan berpikir dalam menyelesaikan masalah, proses pembelajaran fisika menjadi lebih efektif, menjadikan siswa aktif dan membangkitkan motivasi siswa untuk belajar.

\section{KESIMPULAN DAN SARAN}

Berdasarkan hasil penelitian dapat disimpulkan bahwa penerapan discovery learning berbantuan media laboratorium virtual berpengaruh terhadap penguasaan konsep fisika siswa. Hal ini ditunjukkan dengan peningkatan nilai rata-rata penguasaan konsep pada siswa yang diajarkan dengan discovery learning berbantuan media laboratorium virtual lebih tinggi dibandingkan dengan siswa yang diajarkan menggunakan pembelajaran konvensional. Secara keseluruhan setiap sub materi listrik dinamis mengalami peningkatan dengan peningkatan tertinggi terdapat pada materi arus listrik $(88 \%)$ dan terendah pada materi rangkaian listrik (42\%), namun ditemukan peningkatan pada materi alat ukur listrik di kelas eksperimen 1\% lebih rendah dibandingkan kelas kontrol. Selain itu, diketahui bahwa adanya peningkatan pada setiap aspek kognitif dengan peningkatan tertinggi pada aspek $\mathrm{C} 1$ dan terendah pada aspek C5.

Adapun saran yang dapat diberikan peneliti selanjutnya, yaitu: (1) pengaturan waktu sebaik mungkin sehingga tiap tahapan pembelajaran dapat terlaksana secara maksimal, (2) sebaiknya pembelajaran menggunakan media laboratorium virtual dilaksanakan pada ruang laboratorium komputer.

\section{UCAPAN TERIMA KASIH}

Terima kasih disampaikan kepada Tim Hibah Penelitian Strategis Nasional Kemenristek Dikti Tahun 2016 yang telah melibatkan kami dalam penelitiannya, membimbing dan mengajarkan banyak hal, serta memfasilitasi semua proses hingga publikasi ilmiah bersama.

\section{DAFTAR PUSTAKA}

[1] Kosasih, E. 2014. Strategi Belajar dan Pembelajaran. Bandung: Yrama Widya.

[2] Widiadnyana, I.W., Sadia, I.W., dan Suastra, I.W. 2014. Pengaruh Model Discovery Learning terhadap Pemahaman Konsep IPA dan Sikap Ilmiah IPA. Jurnal Program 
Pascasarjana Universitas Pendidikan Ganesha Program Studi IPA. Volume 4.

[3] Putrayasa, I. M., Syahruddin, H., dan Margunayasa, I. G. 2014. Pengaruh Model Pembelajaran Discovery dan Minat Belajar Terhadap Hasil Belajar IPA Siswa. Jurnal Mimbar PGSD Universitas Pendidikan Ganesha. Volume 2 Nomor 1.

[4] Agustine, D. Wiyono, K., dan Muslim, M. 2014. Pengembangan E-Learning Berbantuan Virtual Laboratory untuk Mata Kuliah Praktikum Fisika Dasar II. Program Studi Pendidikan Fisika FKIP UNSRI. Jurnal Inovasi dan Pembelajaran Fisika I (1): 33-42.

[5] Bajpai, M dan Kumar, A. 2015. Effect of Virtual Laboratory on Students Conceptual Achievement in Physics.International Journal of Current Research. Vol 7, Issue 02, pp. 1280812813, ISSN: 0975-833X.

[6] Asril, Z. 2012. Micro Teaching: Disertai dengan Pedoman Pengalaman Lapangan. Jakarta: Rajawali Pers.

[7] Roestiyah, N.K. 2012. Strategi Belajar Mengajar. Jakarta: PT Rineka Cipta.

[8] Ilahi, M.T. 2012. Pembelajaran Discovery Strategy dan Mental Vocational Skill. Jogjakarta: Diva Press.

[9] Nur, M dan Wikandari, P.R. 2004. Pengajaran Berpusat Kepada Siswa dan Pendekatan Konstruktivis dalam Pengajaran. Surabaya: Universitas Negeri Surabaya.

[10] Gunawan. 2015. Model Pembelajaran Sains Berbasis ICT. Mataram: FKIP Unram Press.

[11] Swandi, A. 2014. Pengembangan Media Pembelajaran Laboratorium Virtual untuk Mengatasi Miskonsepsi pada Materi Fisika Inti di SMAN 1 Binamu, Jeneponto. Jurnal Fisika Indonesia. Volume: XVII, Nomor: 52, ISSN: 14102994.

[12] Herga, N. R., Cagran, B., dan Dinevski, D. 2016. Virtual Laboratory in the Role of Dynamic Visualisation for Better Understanding of Chemistry in Primary School. Eurasia Journal of Mathematics,
Science \& Technology Education. 12 (3) :593-608.

[13] Gunawan, Harjono, A., dan Sutrio. 2015. Multimedia Interaktif Pembelajaran Konsep Listrik Bagi Calon Guru. Jurnal Pendidikan Fisika dan Teknologi. Volume 1 No 1.

[14] Dahar, R.W. 1989. Teori-Teori Belajar. Jakarta: Erlangga.

[15] Silaban, B. 2014. Hubungan Antara Penguasaan Konsep Fisika dan Kreativitas dengan Kemampuan Memecahkan Masalah pada Materi Pokok Listrik Statis. Jurnal Penelitian Bidang Pendidikan, Vol 20 No 1, hlm. 65-75.

[16] Anderson, L.W dan Krathwohl, D.R. 2015. Kerangka Landasan untuk Pembelajaran, Pengajaran, dan Asesmen: Revisi Taksonomi Pendidikan Bloom. Yogyakarta: Pustaka Pelajar.

[17] Setyosari, P. 2012. Metode Penelitian Pendidikan dan Pengembangan. Jakarta: Kencana Prenadamedia Group.

[18] Sugiyono. 2015. Statistika Untuk Penelitian. Bandung: Alfabeta.

[19] Hermansyah, Gunawan, dan Herayanti, L. 2015. Pengaruh Penggunaan Laboratorium Virtual terhadap penguasaan konsep dan Kemampuan Berfikir Kreatif Siswa pada Materi Getaran dan Gelombang. Jurnal Pendidikan Fisika dan Teknologi. Volume 1 Nomor 2.

[20] Sari, N., Darmadi, W. I., dan Saehana, S. 2015. Perbedaan Hasil Belajar Fisika antara Siswa yang Belajar melalui Model Pembelajaran Discovery berbantuan Simulasi Komputer dengan Model Konvensional di SMA Negeri 7 Palu.. Jurnal Pendidikan Fisika Tadulako. Vol.3 No.4. 